Studia Anglica Posnaniensia 47/4, 2012

doi: 10.2478/v10121-012-0014-8

\title{
LEXICAL BORROWINGS AND CALQUES \\ FROM AFRICAN AMERICAN SLANG IN POLISH YOUTH SLANG - A STUDY BASED ON A SELECTED INTERNET FORUM
}

\author{
RADOSŁAW DYLEWSKI AND PIOTR JAGODZIŃSKI
}

Adam Mickiewicz University, Poznań

\begin{abstract}
The aim of the article is to present a very preliminary chunk of a wider study of Polish slang, whose aim is to pinpoint lexical influence of American English in broad terms and the usage and understanding among Polish youngsters of various types of borrowings. More specifically, the authors have concentrated on the borrowings of words, phrases and meanings from a sociolect known as African American English to the language of Polish youngsters. To this end, the largest Polish hardcore punk Internet forum has been scrutinized. The conducted analysis points to a discernible, albeit not significant lexical influence of the sociolect on the Polish youth slang, which calls for a more nuanced, survey-based analysis the authors wish to undertake as part of their research project.
\end{abstract}

\section{Introduction}

For quite some time Polish has been heavily borrowing lexical items from British English, items representing an array of semantic fields. Not surprisingly, books, chapters, and essays on Anglicisms in Polish have proliferated. However, due to an increasing popularity of the American variety of English worldwide, Polish has also borrowed some of its lexical elements. Among these one can spot words, phrases, and meanings which might have not or did not originate in American English per se, but in a sociolect known as African American English, especially within its slang level. To the best of the authors' knowledge, the transfer of Americanisms as well as lexemes and phrases from an ethnolect of the Black minority in the United States to Polish constitute an area to which not much, if any, heed has been paid thus far.

Undoubtedly, the popularity of rap music and the whole hip-hop culture among the Polish youth (Garcarz 2005) is a factor instrumental in the process of 
borrowing of lexical elements from the language of African Americans to Polish youth slang. ${ }^{1}$ Interestingly, however, this phenomenon is not only confined to youth circles connected with hip-hop lifestyle, but it can also be traced in the subculture which has been rather resistant to cultural influences of the African American minority in the US. This subculture is known as hard-core punk and its cultural connections with African American heritage are rather loose.

Thus said, the authors of the present essay focus on depicting some of the borrowings found in one of the largest, if not the largest, Polish hard-core punk Internet forums. ${ }^{2}$ This article shows a very preliminary chunk of a wider study of Polish slang, whose aim is to pinpoint lexical influence of American English in broad terms and the usage and understanding among Polish youngsters of various types of borrowings. Importantly, this youth is rather not culturally connected with hip-hop ${ }^{3}$ in a direct way (in the case of young Polish rappers/hiphoppers, the plausible transfer of words, especially referring to either musical or cultural phenomena or both, is relatively obvious).

\section{Theoretical underpinnings}

For a start, two terms - slang as well as African American English - require brief clarification. Lighter (2001: 220) provides the following succinct definition of the former:

\footnotetext{
Slang denotes an informal, nonstandard, nontechnical vocabulary composed chiefly of novel-sounding synonyms (and near synonyms) for standard words and phrases; it is often associated with youthful, raffish, or undignified persons and groups; and it conveys often striking connotations of impertinence or irreverence, especially for established attitudes and values within the prevailing culture.
}

When it comes to the latter, the language of African Americans, i.e. African American English (henceforth AAE) is a sociolect or an ethnolect of the American variety of English. In a nutshell, it is characterized by pronunciation patters different from the mainstream variety, ${ }^{4}$ traces of syntactic elements inherited from indigenous African languages, disparate morphosyntax which is not pre-

1 Markowski (2006: 1617) claims that the English language contributes foreign elements not only to the Polish lexis, "but to the whole linguistic system and also to our culture (limited so far to everyday culture). Not always is it the high culture as evidenced by American film dialogues saturated with vulgar vocabulary".

$2 \quad$ Found at http://forum.hard-core.pl/.

3 This aim will be achieved by analyzing surveys distributed in a number of schools, both vocational and high, initially in the Wielkopolska region.

4 The authors deliberately avoid using the term standard since it is not very appropriate in the context of American English, where this standard witnesses problems with proper identification; hence, the more adequate term General American is used. 
sent in General American, ${ }^{5}$ and some specific vocabulary. As for the latter, Labov (1998: 147) acknowledges the following: "the most distinctive feature of modern AAVE is the rich development of semantic possibilities in the AA system, possibilities that are unavailable and unknown to speakers of other American dialects." It goes without saying that this ethnolect is used mainly by the African American minority in the USA. The purposefully usage of the adverb mainly should be emphasized here - elements of African American word stock, grammar and/or pronunciation are copied and appropriated ${ }^{6}$ by, for example, white rappers who aim at being authentic and treat it as a means of gaining credibility among their listeners.

African American English is understood here mainly as African American English Vernacular, which is "an everyday language because the vocabulary and phrase capture everything from the monotonous to the extreme maneuvers of navigating one's way through life as an African descendent living in America" (Smith 2012: 13).

All this said, throughout the history of American English one can observe the fluctuating process of borrowing of words, phrases, and meanings from African American English, which was a result of three major factors. First, it resulted from dialect contact which assuredly took place on the plantations of the American South, where AAE originated. Second, the wide recognition of music genres traditionally associated with African Americans (i.e. jazz, blues, rap) largely contributed to the popularity of word stock and phraseology of AAE provenience among the whites (thus, AAE has generally transcended ethnic boundaries (Smith 2012: 14)). Third, certain socio-historic events drew public opinion to this ethnic minority. Generally, a number of lexical items were borrowed, initially in a marginalized usage, and as time passed, some of them dropped out of usage, but some, in turn, became interwoven into the mainstream linguistic fabric.

In her 1999 article on the lexical borrowings from AAE into the language of American newspapers, Lee introduces the chronology of the major waves of adapting the words/phrases of supposedly AAE origin by American press. This chronology delineates four major periods in which the lexical items migrated to American English vocabulary and some of them eventually became a part of it:

a) Slavery era (from the beginning of the seventeenth century up until 1865 , i.e. the end of the Civil War);

5 There exists a common misconception that the Afroamerican sociolect is a worse variety of English, especially in older subject literature it is oftentimes referred to as 'slang'. As far as grammatical structures are concerned, especially those pertaining to tense and aspect, this variety of English is extremely rich and exhibit structures unparalleled in White American English.

6 To use Smitherman's (2006) term. 
b) Jazz era (embracing the years 1920-1940);

c) Civil Rights Movement (covering the years 1955-1970);

d) Rap/hip hop era (from 1980s until now).

A number of elements of AAE word stock, especially these from the first period mentioned by Lee, became so deeply cemented into the US English or its dialects that no longer are they recognized as African Americanisms and their etymology can be a subject matter of debates among linguists. ${ }^{7}$ Needless to say, next to the transfer of words or phrases per se, there is also a type of transfer on the semantic level. This phenomenon is based on assigning (or simply borrowing) new meanings to popular English words (semantic dialectisms). By way of example, in AAE the popular adjective bad, next to its dictionary designation, has undergone a process of semantic amelioration to gain a new and totally opposite contextual meaning. ${ }^{8}$ A case in point is also the word kitchen. Apart from its widely known meaning, the word has acquired a new and totally unexpected AAE denotation, i.e. "a single curly hair growing out of a birthmark or a mole located on one's neck". Needless to say, the usage of such unorthodox meanings of common words by non-native speakers or among those unfamiliar with their semantic intricacies can hamper communication or, at best, lead to certain misunderstandings.

In the case of the process of borrowing vocabulary elements from AAE to languages other than English it can operate according to two scenarios.

Scenario a) (indirect transfer):

7 A classic example would be a verb usually assigned to Southern American English word stock, namely to tote (meaning 'to carry') whose derivation was thought to have originated in east African languages (following http://www.etymonline.com, date of access 17.02.2011). However, the Oxford English Dictionary states that the etymology of the word is unknown. According to this source, there is yet another hypothesis which stipulates that the word comes from the languages of the native inhabitants of the US. Both hypotheses, nevertheless, have yet to be verified.

8 In the subject literature one can find two etymologies of the positive meaning of the word $\mathrm{bad}$. On the one hand, slaves working on the plantations altered the meaning of common words in order not to be overheard by plantations overseers. On the other hand, though, in some African languages one can find examples of the process of meaning reversal, in the course of which word carrying negative meaning acquires the opposite denotation. 


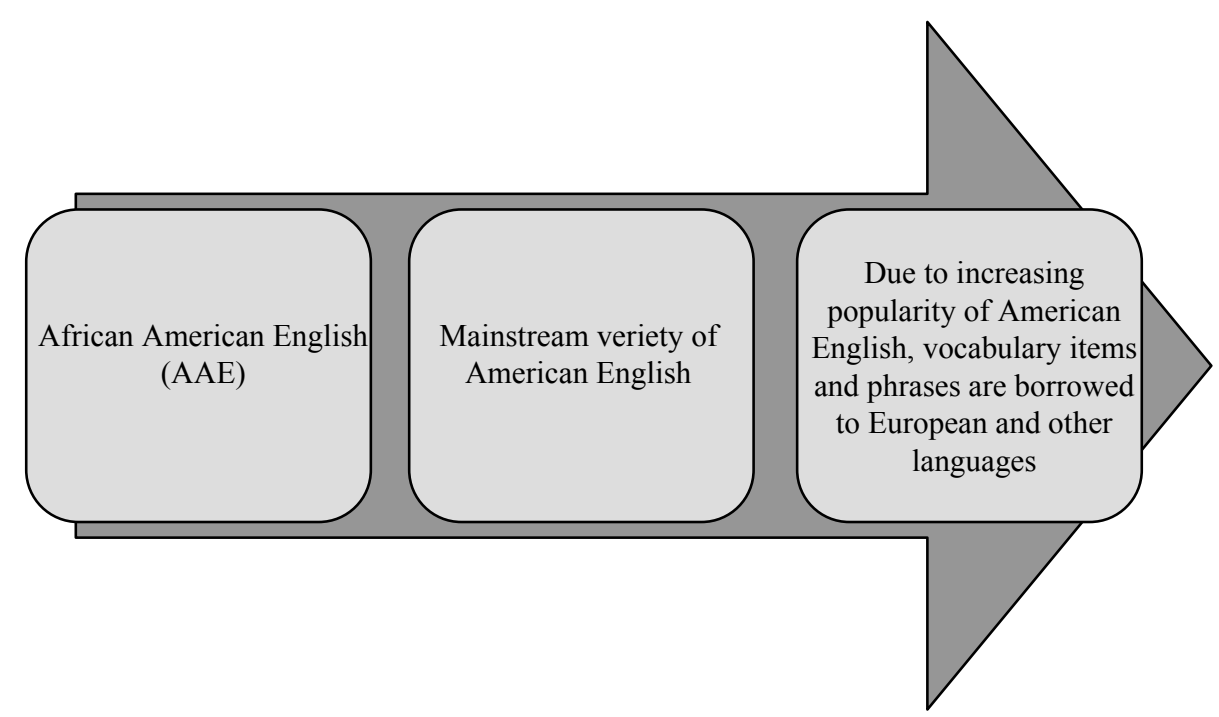

Scenario b) (direct transfer)

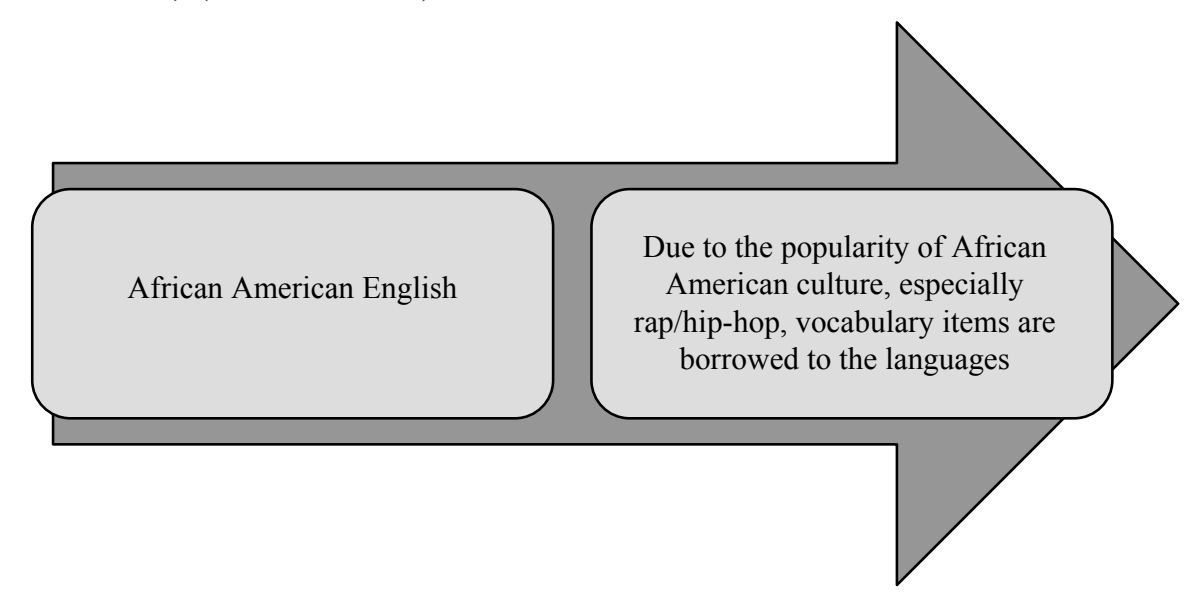

Explicit within this perspective is the fact that the popularity of such modern media as television, radio, and especially the Internet has largely contributed to the direct spread of elements of African American culture (scenario B) into languages other than English, even though scenario A used to prevail. In general, the recognition of hip-hop as a culture has been instrumental in the elements of AAE crossing the border of the USA. Geneva Smitherman, a renowned linguist and a propagator of AAE, in her 2006 book claims that African American cultural elements as well as linguistic elements deriving from African American English are borrowed by rap musicians and music fans in geographi- 
cally distant places: "[t]here are Hip Hop heads incorporating Black linguistic terms and expressions in France, Spain, the Netherlands, Poland and throughout Europe, in Africa, the Middle East, Japan, the world" (Smitherman 2006: 117; italics by RD and PJ).

Smitherman's claim, although unsupported by any examples from, for instance, Polish, has provided a strong stimulus for the present authors to check empirically if there is any impact of AAE on Polish youth slang. ${ }^{9}$ At first, the authors have decided to analyze hip-hop oriented internet forums. As stated earlier, in this particular context borrowings are relatively obvious, confined to the specific semantic area and that indeed supports Smitherman's suggestion. This is pertinent to the hip-hop youth sociolect or jargon of Polish rappers: beat or the pseudo-phonetic form bity, b-boy, hip-hop, man, MC, rap (noun), rapować (verb, to rap), yo, etc. For example:

Dobry MC nie może bać się nikogo. Na imprezach staje przecież twarzą w twarz z publiką. Nawet jeśli sam Bóg, Mojżesz, Abraham czy Jezus zeszliby na ziemię, żeby stanąć z nami do bitwy, dalibyśmy radę. Skopalibyśmy im tyłki!” Te słynne słowa Grandmastera Caza, jednego z pierwszych hiphopowych MC, Wydają się dziś oczywiste. Ale nie było tak pod koniec lat 60., kiedy Caz działał jako jeden z wielu MC. Wtedy Master Of Ceremonies (mistrz ceremoni) był drugoplanową postacią składu. Gdy powstawały pierwsze rapowe rymy, a hip-hop dopiero zapuszczał korzenie, funkcja MC sprowadzała się do roli... konferansjera. Inne tłumaczenia skrótu wyjaśniają jeszcze lepiej jego ówczesną rolę: Microphone Controller (czyli ktoś będący w posiadaniu mikrofonu) lub bardziej slangowo Mic Checka („sprawdzacz” mikrofonu) przedstawiał zgromadzonym, kto stoi za gramofonem. Zapowiadał, co będzie grane i czasem „wciskał” w przerwach między kawałkami jakiś krótki tekst... ${ }^{10}$

[A good MC can't be afraid of anybody. At parties you have to stand face to face with the crowd. Even if God himself, Moses, Abraham or Jesus descended from heaven to face us in battle, we would manage to beat them. We would kick their asses!" These famous words of Grandmaster Caza, one of the first hip-hop MCs seem obvious today. But it wasn't like that toward the end of the 1960s, when Caz was one of many active MCs. At that time a Master of Ceremonies was a backdrop member of the line-up. When first rap lyrics were created and when hip-hop started to emerge the function of an MC boiled down to being a ... spokesman. Other translations explain better his role at the time: Microphone Controller (i.e. somebody who was in charge of the microphone) or to be more slangish Mic

9 In the Polish context, in an attitudinal accent perception study it has been shown by Jagodziński (2009) that representatives of Polish youth exhibit a certain level of familiarity with the AAE accent, which in line with Smithermans's claim and points to the spread of the variety outside the US.

10 Original spelling and punctuation have been retained. http://tina88.bloog.pl/id,2163671,title,Kim-jest-MC-oraz-DJ,index.html?ticaid=6ca30 (date of access: 10.07.2001). 


\begin{abstract}
Checka (i.e. the "checker" of the microphone) who introduced to the crowd those who stood behind the decks. He informed what was to be played and in-between cuts he squeezed in a short comment at times.]
\end{abstract}

The passage which constitutes an attempt at explaining the acronym $M C$ contains words which have been borrowed by Polish hip-hoppers/rappers from US English(es). Among other words and phrases, there is MC (Pol: mistrz ceremonii), hip-hop $M C$, and crew (the Polish equivalent is sktad).

Setting aside the semantic field of rap/hip-hop, the authors wanted to check whether this impact seems any broader than that and surfaces in slang/ language of deep level of informality used by other youth cultures. In an attempt of finding a youth group which does not directly draw on African American lifestyle and music and where borrowings are not that apparent, the authors have stumbled upon an Internet forum grouping fans of the hard-core/punk genre. Such a forum seems interesting from the linguistic point of view: there one can find users of slang or largely informal version of the Polish language - not necessarily teenagers - who might have not been exposed extensively to African American culture, ${ }^{11}$ due to hard-core/punk being rather not inspired by it. ${ }^{12}$ The set of examples elaborated on below has been drawn from the study of this forum.

When it comes to the methodology applied in the present study, in order to check if a given element is of AAE origin, the authors have used the lists of words/phrases/meanings from publications written by African American scholars - Green 2002, Lee 1999, Mufwene 2003, Rickford - Rickford 2000, and Smitherman 2000 and 2006. It has been assumed that a given word, phrase or meaning is considered to be of African American provenience if it is treated like that by authors of at least two of the above articles and monographs (after Lee 1999 and Dylewski 2008). Additionally, the authors have verified the compiled list with the most extensive English dictionary to date, i.e. the Oxford English Dictionary, $2^{\text {nd }}$ edition. A given word, phrase or meaning has been taken to come from AAE if it has been labeled appropriately in the dictionary entry.

The number of the examples excerpted from the forum is not high, hence grouping them in order other than alphabetical seems useless. Each item has been provided with a linguistic commentary and classified according to the following criteria, wherever applicable:

11 Of course, such a statement might be idealistic since listening to hard core/punk does not automatically exclude being an ardent follower of fan of rap/hip hop. It has been assumed here, however, that the influence of African American is not as prominent as in the case of Polish rappers and hip-hoppers.

12 There are obviously exceptions where the line-up of a band consists of colored members. 
1) Subject matter: ${ }^{13}$

a) Borrowings proper, i.e. words taken together with their meaning (alternatively with assimilated spelling and pronunciation);

b) Structural borrowings, i.e. calques which are accurate appropriations of foreign construction, accurate translations of the constitutive elements:

- word-formation calques, i.e. words created according to foreign wordformation patterns with the use of native morphemes, e.g. przystówek (Latin adverbium,), przedstawienie (German Vorstellung), zaimek (Latin pronomen);

- phraseological calques, i.e. appropriations of fixed word patterns, e.g. nie ma sprawy (English it doesn't matter);

- semantic calques, i.e. giving the Polish words new meanings characteristic of their foreign counterparts, e.g. cienka aluzja (on the basis of the Russian counterpart), instead of: subtelna or delikatna aluzja.

c) Semantic borrowings, i.e. taking only the meaning of a word, which supplements the already known meaning, e.g. Polish verb korespondowac (prowadzić korespondencje), which is an old Latin borrowing.

2) Degree of assimilation, which can be further subdivided into:

a) Citations - word/phrases transferred from another language with the same spelling and pronunciation, e.g.: bye bye;

b) Words partly assimilated, i.e. those which are considered to be foreign because of their pronunciation, spelling, and/or lack of inflection, but which, nevertheless, are deeply rooted, for instance, in the Polish lexical system, e.g.: dżudo, guru, tabu, etc.

c) Fully assimilated words, i.e. those that are considered to be native because of their conforming to Polish spelling and inflectional paradigms.

The examples illustrative of some of the above-given types have been extracted from http://forum.hard-core.pl, which is the Internet forum in focus. The discussion has been also supplemented with entries from the Miejski stownik slangu $i$ mowy potocznej (http://www.miejski.pl/), which is a Polish answer to "Urban dictionary" (http://www.urbandictionary.com). The study embraces the time span of three years 2010-2012. ${ }^{14}$

\footnotetext{
13 According to Nowy stownik poprawnej polszczyzny PWN, edited by Andrzej Markowski as well as http://pl.wikipedia.org/wiki/Zapożyczenia_językowe (date of access: 27.06.2011).

14 All examples can be found using the search engine available at: http://forum.hardcore.pl/search.php.
} 


\section{Discussion}

The following words, phrases, and meanings have been identified in the forum subject to scrutiny. All of them seem to be of African American origin; they have spread because of the influence of the sociolect used by the representatives of the said ethnic minority in the US.

Beef, bif (English: beef)

(noun, usually in a phrase to have beef with somebody) - "a quarrel, conflict between groups or single artists/performers over artistic matters"; ${ }^{15}$ The etymology of this meaning is not certain. Most probably, the word beef gained a new connotation at the end of the nineteenth century when American soldiers did complain about the quantity and the quality of beef rations in encampments. ${ }^{16}$ However, Smitherman (2006: 22) and other scholars include this lexeme under the category of African American meanings. In both English and Polish this meaning of beef is used widely in the context of rap musicians who engage in artistic conflicts or so-called dis (see below).

Beef is also a part of the phrase - mieć z kimś beef, which is a calque of an English phrase to have beef with somebody. In the analyzed forum beef can be used as a borrowing proper (or an inserted citation) (example 1$) ;{ }^{17}$ it can also undergo partial assimilation and acquire Polish spelling and inflections (example 2):

1) - na czym polegal ten beef?

- chyba na tym że jedni drugim zabronili rozłożyć merch na koncercie a potem to się ciagnęło ... ogolnie straszna glupota;

[- what was that beef about?

- I guess it was about one group forbidding the others to set up a merchandize stand at a gig and it was continued ... generally it was awful tomfoolery]

2) Ja pamiętam takie bify: Agnostic Front vs. maximum rock'n'roll... [I remember such beefs as: Agnostic Front vs. maximum rock'n'roll...]

As visible from the examples above, beef is used not only in the hip-hop context, but can refer to a rather long-lasting argument between groups or individuals. The word per se as well as the phrase in which it frequently functions wit-

15 Obviously this meaning is so far marginal, it exists alongside the primary meaning "the flesh of an adult domestic bovine (as a steer or cow) used as food" (Merriam-Webster Dictionary, www.m-w.com, s.v. beef).

$16 \mathrm{http}: / / \mathrm{www} . e t y m o n l i n e . c o m$, date of access: 17.01.2011.

17 All citations retain their original spelling and punctuation. 
ness popularity in Polish slang because they filled in the void in the lexicon of the informal layer of Polish. Due to its character and overtones which are associated with "cool discourse", beef is employed to maintain what Fox (1977) calls the "freshness and immediacy".

chill (English: a chill, to chill)

The lexeme exists in its base form next to its variants: chilling, wychillować, chilloucik, chill! (as well as full assimilated forms such as czil, wyczilować, etc.). To chill means 'to relax', 'cool down, to be chilled out (Polish wychillowany) refers to being 'laid back'. The word is obviously of English origin, however, in the slang of African American youth ${ }^{18}$ the phrase chill out has acquired a new meaning. This meaning of the word/phrase is used in the Polish youth slang irrespectively of their musical preferences:

3) Posi klimat na maxa $\mathrm{z} z a^{* * *}$ ta zaloga!! Na miejscu, pierwszego dnia chilloucik... Napoleon Dynamite! yeaah! myslame ze sie poplacze ze smiechu!; [Absolutely posi $^{19}$ atmosphere with a $\mathrm{f}^{* * *} \mathrm{~g}$ good crew. On the first day when we reached our destination, there was a little chill-out. Napoleaon Dynamite! Yeaah! I thought it would have me crying with laughter!];

4) czemu niby? fajnie bedzie. Wycziluj.

[why then? It's gonna be fun. Chill out'].

This lexeme has been assimilated on the morphological level. Thus, it can acquire prefixes and suffixes (wychillować). It can also function as a diminutive (i.e. chilloucik). Interestingly, variants of the Polish equivalent of chill, to chill out, and to be chilled out namely luz, wyluzować się, być wyluzowanym, być ok in some contexts adopt a quasi-English spelling, looz:

5) Stary looz ... to była tylko ogólna informacja i kilka komentów więc nie ma co piłować tematu;

[Man, relax... That was just a general piece of information and a few comments, so it's no use dwelling on the topic];

6) Reszta składu spoko looz zero gwiazdorki ale ten to już przesadził. Dobrze ***, że moczył nóg $\mathrm{w}$ solance po koncercie.

[The rest of the line-up was $o k$, no showmanship but this one pushed it too

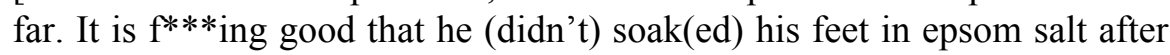
the concert].

18 First examples included in the Oxford English Dictionary come from rap lyrics. This phrase has been assimilated by the American youth slang in no time.

19 Posi is a clipped form of "positive." The form started to exist in the positive hardcore context, where positive hardcore is a sub-genre of hardcore punk. 
dis (English: a dis(s), to diss)

Dis denotes showing disrespect, originally toward a rapper with whom one was engaged in a long-standing beef; the etymon of the form dis $(s)$ is most probably the word disrespect. In the US English dis(s) has undergone the process of transfer into white speech and what follows semantic extension - it can thus be used in contexts other than the ones associated with hip-hop culture (for example, a teacher can dis an enervating student). Both in English and Polish this lexeme can function either as a verb or a noun.

Dis has existed in Polish slang for quite some time and it has its entry in Miejski stownik slangu $i$ mowy potocznej ${ }^{20}$ which gives the following meaning, which, in fact, is based on the primary English meaning:

\begin{abstract}
Obraźliwy atak słowny kierowany w konkretną postać/artystę. Z dissem najczęściej można się spotkać podczas potyczek freestyle'owych. Dobry diss polega na wytknięciu negatywnych cech przeciwnika, naśladowaniu jego stylu lub na przekształcaniu fragmentów jego twórczości w sposób obnażający ich słabości. [An offensive verbal attack on a concrete person/artist. One can come cross dis during freestyle battles. A good dis rests on pinpointing negative aspects of the opponent, mimicking their style or altering fragments of their work in order to expose its weaknesses].
\end{abstract}

The practice of verbal dueling constitutes ritual conflict or banter in which the expressions of AAE origin serve to attack and possibly to heighten or boost the face damage inflicted on the opponent (Culpeper 2011). One may also risk a claim that the participants' use of the words of AAE provenience gives them additional advantage over their opponent making their performance more credible in the eyes of other hip-hop immersed over hearers/viewers.

In the forum one can find numerous examples of the noun $\operatorname{dis}(s)$ or the verb (z) dissować somebody or something:

7) - Człowieku, przerywasz opcję na następny dobry diss; [- Man, you're wasting a chance for a good diss];

8) - Widze ze lubisz ,dissowac”?...powodzenia internetowy wojowniku; [- I can see you like dissin'?... Good luck, you Internet warrior];

9) Więc można zdisować Grabaża, że dla studentów, że do grilla...

[So you can diss Grabaż that his music is cut for students, that it goes well with barbecue...]

20 http://www.miejski.pl/slowo-Diss; date of access: 18.03.2012. 
gówno (English: shit)

This item frequently surfaces with a quantifying adjective dobre (good), infrequently without it (c.f. example 10). It constitutes a case of a semantic borrowing where a taboo word with an overtly negative connotation has acquired a positive meaning. Of course, this rather marginal denotation exists next to the prevalent negative one:

10) jestem kupiony! tutaj mogę się z czystym sumienim przyłączyć do zachwytów. temu zespołow przy debiucie nie brakuje niczego do pierwowzorów (czy raczej pierwowzoru - Sędzia po polsku by kabaretowo bzmiało w sumie heh). a to w PL wydawało się niemożlie wręcz. chcę to gówno!!!

[I'm in! With a clear conscience I can join those who admire the band. This debut act has everything the original bands had (or rather just the original one - 'Judge' would sound absurd in Polish). ${ }^{21}$ All that seemed almost impossible in Poland. I want that shit!!!

11) ... Napalm Death "Utilitarian" - bardzo dobre, twarde jak beton gowno. Polamane, nie nadaje sie sie do biegania;

[...Napalm Death "Utilitarian" - very good, concrete-hard shit! Broken riffs, can't be listened to while jogging];

12) Nie pije już czwarty dzień i słucham thug $\mathrm{x}$ life. Dobre jest to gówno.

[I haven't been drinking for four days now and I'm listening to thug $\mathrm{x}$ life. This shit is good. $]^{22}$

The meaning at issue most plausibly comes from the expression good shit, which originally referred to good-quality marihuana or heroin. The expression has also undergone semantic expansion and can be used with reference to virtually anything (it is synonymous to good stuff).

gruby (English: phat)

It has a number of variants in Polish: grubaśny, ttusty, wypasiony - it is a semantic borrowing, which generally derives from African American semantic and orthographic interpretation of the word fat. Although the word has retained its original pronunciation, it has undergone a spelling modification which resulted in phat; simultaneously it has acquired a new meaning. Following the Oxford English Dictionary (s.v. phat), the word (1) can refer to people, in particular to attractive women and (2) is used especially with reference to music good, excellent, fashionable.

21 This Polish band is compared here to the seminal 'prototypical' band - Judge - which was a New York-based straight edge act.

22 Reference is made here to abstaining from alcohol because ThugXlife represents straight edge stance, whose one of the necessary elements is sobriety. 
Loan translations in Polish exist in exactly the same meaning:

13) Ufff, pierwszy dzień za nami! Było grubo! Pokładające się na ziemi jednostki można było już zaobserwować zanim jeszcze zaczęto wpuszczać do klubu;

[The first day is over! That was phat! You could observe staggering individuals yet before the club was open];

14) no to elegancko! postaramy się być koło tej 15 tej; haha będzie grubaśnie; [Great then! We will try to make it at 3 o'clock; haha it's gonna be phat!];

15) Na pewno to nie drugie Catharsis, masz rację. Choć może to i dobrze ;) W każdym razie dla mnie jest tlusto, świetna, mocna rzecz, a do tego niewątpliwie oryginalna wielce :D.

[This is surely not a second Catharsis, you're right. But then it seems good this way;) Anyway, for me it's a phat, good, hard and, what is more, undoubtedly original thing :D].

\section{hipster/hipsterka (English: hipster)}

The latter (hipsterka) can be sometimes used as either a feminine noun, however, it is rather collective noun designating a group of hipsters or the way of acting/dressing in a hipster-like way. These are adjectival nouns coming from the adjective hip which, in turn, is a variant of the word hep, both of which designate somebody who knows what is in, what is fashionable, etc. The Dictionary of Foreign Expressions and Foreign Words (Polish: Stownik Wyrazów Obcych $i$ Zwrotów Obcojęzycznych) by Władysław Kopaliński gives the following definition: "hipster, hepster, English., music. a devotee of jazz music; a devotee of fashionable and elegant clothes and novelties in general."

The etymology of both of the said variants is not known. However, the lexemes hep/hip (adjective) and hepster/hipster (noun) were propagated in the first half of the twentieth century, i.e. in the period when jazz culture in the US was in full bloom. Hipster returned to popular usage in English toward the end of the 1990s.

At present, not only does it exist in the Polish youth slang but also (or rather) in the less formal language. It is characterized by certain 'cultural' or 'connotational duality'. On the one hand, it seems to carry slightly pejorative overtones: it is the way of dressing and behaving which is subject to ridicule. A hipster is somebody (probably) from an affluent family, frequently a user of an Iphone, a Starbucks-goer, somebody who seems not to care about their looks, but in reality is, indeed, concerned about it to extremes. A hipster is also superficially decadent and/or hedonistic and claims to be a part of the alternative culture and tries - sometimes in vein - to defy the mainstream. On the other, hipsters can be treated as some sort of a newly emerging subculture consisting of people, not 
only youngsters, who visit special clubs cut for hipsters, dress appropriately in pricey vintage clothes and listen to music dubbed 'off' played at concerts/festivals attracting this specific audience. In the examples found on the Internet forum in question, however, the negative connotation prevails:

16) Ale jeśli już mają ją mieć wszystkie punki, to po to, żeby nie miał jej żaden hipster, bo nie chcemy przerzucać się na pisanie kawałków o esspresso i mokasynach;

[But if all the punks are to have it, then not a single hipster should have it, because we don't want to end up writing cuts about espresso and moccasins];

17) ...bo Fucked Up brzmieli mega slabo, atmosfera na koncercie tez tragiczna. jeszcze kilka lat temu grali naprawde $\mathrm{z}^{* * *}$ te gigi a teraz sama hipsterka na koncertach.

[...because Fucked Up sounded awfully bad, the gig atmosphere was also a disaster, a few years ago they played some $\mathrm{f}^{* * *} \mathrm{~g}$ good gigs and now only hipsters show up at their concerts].

nigga, please or nigga please

In the mainstream variety of English the $n$-word is a politically incorrect taboo item. In the ethnolect of African Americans the word nigga (as its variants) has a plethora of meanings and connotations starting with the negative one (or rather its rhotic variant nigger is regarded as racial slur), through neutral and finishing with the positive one (in the case of the latter, nigga might be interpreted as an acronym standing for: Never Ignorant Getting Goals Accomplished, cf. Smitherman's 2006 chapter). The expression nigga please was popularized by the African American standup comedian Chris Rock in one of his sketches called "Nigga cereal", the purpose of which was to ridicule American political correctness.

When used on the Internet, this expression serves two parallel purposes: to describe an interlocutor in a sarcastic way and to express doubt as to the merits of their argumentation. Nigga please is frequently found as a part of the strategy of sarcasm (Culpeper 1996), in which the surface realization of impoliteness gains an opposite, i.e. polite meaning. A Polish counterpart of this expression can be daj spokój (English: give me a break), pleciesz głupoty (English: you are talking bullshit), etc.

The following Figure illustrates the use of the expression in question: 


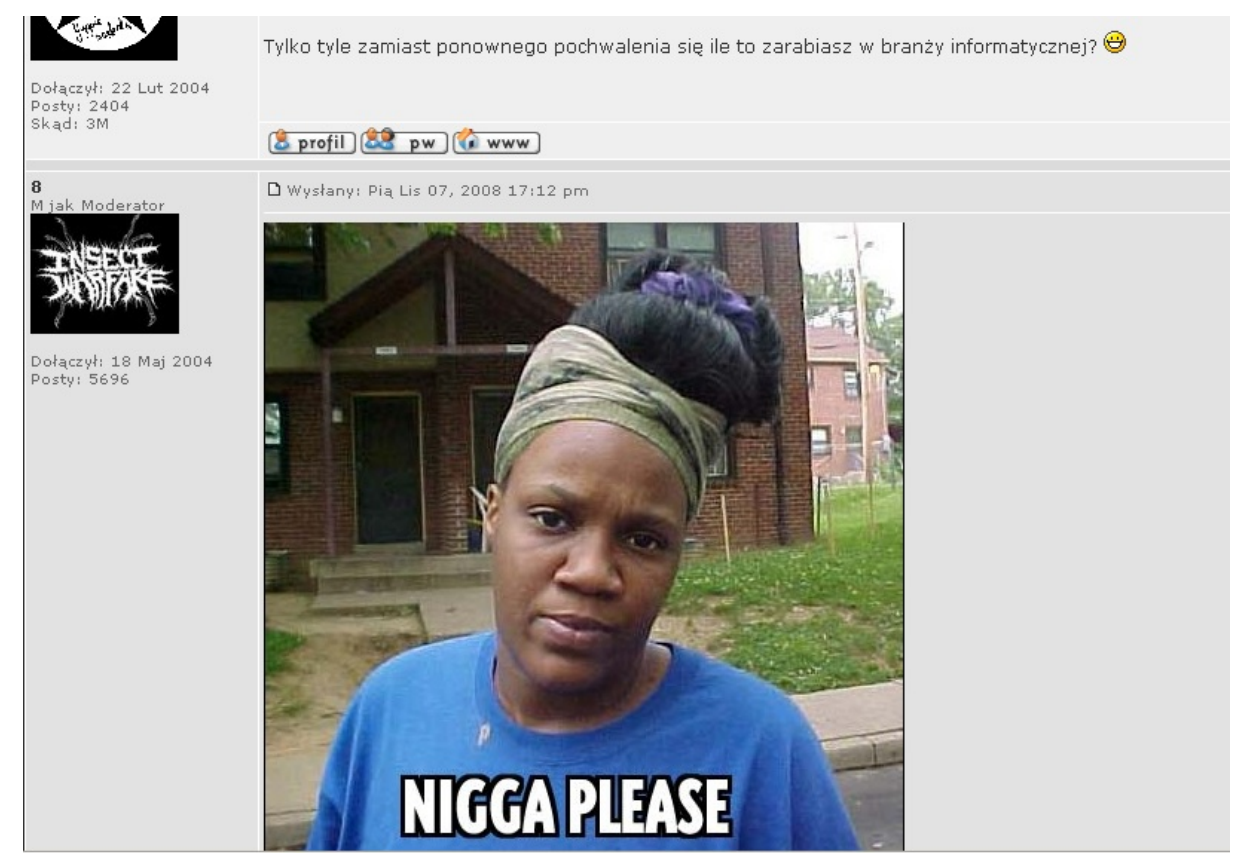

Figure 1. A screenshot illustrating the usage of the politically incorrect phrase nigga please.

Here one can observe that the user of the Internet forum is being sarcastic toward his interlocutor, and the expression in question serves to boost the superficial impoliteness. In fact, more specifically, the phrase is used here as a way to express comity with the interlocutor.

Alongside the original version taken from English (i.e. insertion), one can find a calque of the following kind, where next to nigga please one can find sentence-initial jol (English: yo):

18) jol, bo zeby porządnie moshować trzeba byc twardym, a twardzi zawsze budza respekt... czarnuchu prosze, dawno nie slyszalem takiego steku bzdur!

[yo, in order to mosh well you need to be hard, and those who are hard are respected...nigga please, I haven't heard such bullshit in a long time!]

Undoubtedly, the usage of elements taken from AAE serve here to express a certain degree of contempt mixed with a dose of sarcasm and irony. This, in turn, shows the strong disagreement with the interlocutor's opinion(s). 
propsy (English: props)

This word comes from the English adjective proper (according to some sources proper respect) and is used in the context of approving the activities one considers proper and the ones approved of.

19) jeden ... gigów na jakich byłem w wagonie propsy dla core-poration za zrobienie tego, licze w przyszłości na kolejne takie troche niestandardowe dla c-p pozycje na deskach wrocławskich klubów.

[That was one of the ... shows I have ever been at, props go to coreporation for organizing it. I'm looking forward to other - a little nonstandard as for c-p - events on the stages of Wroclaw's clubs.]

sprawdzić coś/obczaić (English: to check sth out)

Both come from an expression of African American provenience to check something out or check it out, man (see example 20, where the whole phrase has been translated to Polish and used accordingly). It can also be used in a jocular manner where the borrowed phrase follows the pseudo-phonetic spelling convention: czek dis att.

20) True Colors - sprawdz to człowieku;

[True Colors - check it out man];

21) wg najnowszych badań laboratorium dextera, jest to ćwiczenie, które najbardziej aktywuje biceps ... po drugie obczaj gościa z vegan bodybuilding. [according to the newest research from dexter's lab, this is an exercise which best activates biceps ... Secondly, check out the guy from vegan bodybuilding].

word/stowo (English: word)

Word comes from a rap/hip-hop slang (most probably derives from the phrase word up) and serves as a laconic means of expressing utter agreement with the previous speaker/interlocutor; in fact, it is an antonym of nigga please.

Among the attested examples, this word exists as a borrowing proper (word), it can undergo a partial morphological assimilation (augmentation - wordzicho, tordzicho); at times one can find a linguistic calque (stowo).

22) panie to jest skandynawia, tam jest troche inne mentality niz u nas na zadupiu kapelka jak najbardziej na plus i wordzicho, ze na scenie mozna wskazac wiecej ch***ch i infantylnych bandow...

[man, this is Scandinavia, they have a different mental attitude than we do here in the dead end village, the band is very much en plus and word. There are more $\mathrm{f}^{* * * \mathrm{~g}}$ poor and infantile bands in hard-core punk... 
23) ... taka moja dygresja po 45 godzinach wykładów ewolucja i isnienie Boga to dwie niewykluczajace sie teorie no i tordzicho:) a teoria panspermii hm.. co tu polemizować...

[... that is my digression after 45 hours of lectures; evolution and the existence of God - these are two theories that are not mutually exclusive and word:) and the pan-sperm theory, well ... nothing to argue about...

24) - brutal krew karate jest przej*nie życiowy :D

- hehehe stowo! świetne numery, na to liczyłem.

[- it is brutal, blood, karate, it's f***g based on real life :D

- hehehe word! good songs, that's what I have counted on].

ziomek (English: homeboy, homie)

It exists alongside such associated diminutive and augmented forms as: ziomuś, ziomal, ziom, zioom, zia, etc. This is an example of a semantic borrowing where the original lexeme $\mathrm{e}^{23}$ has undergone the process of semantic extension and is used to refer to somebody who comes from the same neighborhood, or in AAE, hood (Polish: dzielnia) and/or who shares common interests (most often musicoriented ones). This extension has been operative under the influence of the lexeme homeboy as well as its derivative homie. More formal Polish equivalents can be the following expressions and words - bliski kolega, kumpel, etc.

25) jest sprawa mój ziom ma trzy wolne miejsca z Wro do Pzn (w dwie strony) jeśli ktoś reflektuje niech piszę do mnie na pw;

[the issue looks like that: my homie offers three free seats from Wroclaw to Poznan (both ways); if you're interested write me a private message];

26) no, ma smak tak jakby fasoli albo otrębów. żeby tego nie było czuć trzeba mocno posłodzić jak dla mnie. moj ziom nawet ma teorię, że tak jest jak się kupuje tanią soje, bo ona jest na pasze dla zwierząt, a dla ludzi jest taka 'bio' i wtedy mleko wychodzi dobre:>.

[yeah, it tastes like beans or bran, if you want to get rid of the taste you need to sweeten it up. my homie has come up with a theory that if you buy cheap soy beans, they taste like that because it is animal fodder; the 'bio' variety is for people and then the soy milk is good :>]

The diminutive form - ziomus - is most often used in the process of exchanging arguments, when the forum user aims at expressing a condescending attitude toward their interlocutor, see example 27:

23 Following Stownik Języka Polskiego (http://sjp.pwn.pl, date of access: 21.04.2011): 1. «a person coming from the same country, the same neighborhood, place» 2. «a member of association (ziomkowstwo)» 
27) no ladnie, pandzia ta raza pojechal jakims przydupasem $z$ oeneru - jak zwykle pop***lo ci sie forum ziomus...

[just great, this time Panda showed up with a buddy from ONR - as always, you have $\mathrm{f}^{* * *}$ ed up the forums, homie...]

\section{Conclusion}

First of all, it has to be said that certain Internet forums connected with music in broad terms constitute an excellent source of (youth) slang due to an unrestrained freedom of both expression and style. An analysis of one of such forums has shown that borrowings from AAE are present there, albeit not in a significant proportion and all in all, the lexical influence of this sociolect is not as "fast and furious" as Smitherman (2006) would like to think.

Anyway, the scarcity of borrowings from AAE only partially corroborates Smitherman's (2006) stance referring to their presence in other languages, including Polish. Needless to say, in the majority of cases the timespan in which a given lexeme is used is rather short. The borrowings appear and cease to be used according to prevailing trends and their use is in a constant state of flux. Sometimes, their usage is confined to the group of users exchanging ideas at a given forum. Nevertheless, it should be noted that items of AAE provenience are incorporated not only by "hip-hop heads", but also people being into totally different genre of music. This is so, probably, due to the "coolness" of African American culture among young people. This coolness encroaches onto its lexicon and phraseology and, ultimately, their users, irrespectively of the geographical region they hail from, are also associated with the aforesaid quality.

Additionally, one can say some of items listed above are used in certain pragmatic situations such as sarcasm (mock politeness) (cf. Culpeper 1996) or as a said way to express a relaxed attitude to a subject at hand or the interlocutor. All of them, as stated above, are markers of the user's "coolness" and their being 'handy' with the witty and up-to-date language. In certain occasions one can even go as far as to claim that the use of the borrowings is a sign of a rather snobbish attitude. ${ }^{24}$ To some extent this claim goes in tandem with what Lee reports for journalistic discourse in two fragments of her article: (1) "According to McCrum, Cran and MacNeil $(1986,234)$, the white journalists who reported on the Harlem jazz scene would "drop the [jazz musicians'] words and phrases into their columns "to show how smart and up to date they were"" (1999: 370) and:

24 A good example found in the source at issue, although not dealt with in the section devoted to discussion, is the phrase my bad, which is indicative of the user's knowledge of English. 
(2) "Journalists attempt to create an image of "coolness" and "hipness" through the use of well-established or popular black slang expressions such as cool, gig, hip, and hot" (Lee 1999: 379).

Finally, Markowski (2006) maintains that not only should linguists analyze Anglicisms in the Polish language, but also they should focus on borrowings from American English, i.e. Americanisms. This list of borrowings from two major varieties of English should be supplemented by 'African Americanisms' which to some extent, at least, managed to get into contemporary Polish slang thanks to the popularity of African American culture, with emphasis on rap music and the hip-hop culture per se. It is hoped that a more detailed study, based on surveys will reveal more AAE elements hidden in the language of Polish youngsters.

\section{REFERENCES}

Algeo, John (ed.)

2001 The Cambridge History of the English Language. Volume VI. English in North America. Cambridge: Cambridge University Press.

Culpeper, Jonathan

1996 "Towards an anatomy of impoliteness", Journal of Pragmatics 25: 349-367.

2011 Impoliteness: Using language to cause offence. Cambridge: Cambridge University Press.

Dylewski, Radosław

2008 "Selected words, phrases, and meanings of (African) American provenance in White American English: A corpus based study", Kwartalnik Neofilologiczny LV (3): 243266.

Fox, Walter

1977 Writing the news: Print journalism in the electronic age. New York: Hastings.

Garcarz, Michał

2005 “Kultura Hip Hopu - współczesny model życia także nastoletnich Polaków”, in: Krystyna Pietrzycka-Bohosiewicz - Aleksander Wawrzyńczak - Władysław Mariczenko (eds.), 39-49;

Green, Lisa J.

2002 African American English: A linguistic introduction. Cambridge: Cambridge University Press.

Jagodziński, Piotr

2009 "The perception of the African American Vernacular English accent among the students of the School of English, Adam Mickiewicz University", in: Grzegorz Michalski - Bartosz Wiland - Katarzyna Dziubalska-Kołaczyk - Jacek Witkoś (eds.), 109117.

Kopaliński, Władysław

Slownik wyrazów obcych i zwrotów obcojęzycznych. <http://www.slownik-online.pl.> 
Labov, William

1998 "Co-existent systems in African-American vernacular English", in: Salikoko S. Mufwene - John R. Rickford - Guy Bailey - John Baugh (eds.), 110-153.

Lee, Margaret G.

1999 "Out of the hood and into the news: Borrowed Black verbal expressions in a mainstream newspaper", American Speech 74: 369-389.

Lighter, Jonathan E.

2001 "Slang", in: John Algeo (ed.), 219-252.

Major, Clarence (ed.)

1994 Juba to jive: A Dictionary of African American slang. New York: Viking.

Markowski, Andrzej (ed.)

2006 Wielki słownik poprawnej polszczyzny PWN. Warszawa: Wydawnictwo Naukowe PWN.

McCrum, Robert - William Cran - Robert MacNeil

1986 The Story of English. New York: Viking.

Michalski, Grzegorz - Bartosz Wiland - Katarzyna Dziubalska-Kołaczyk - Jacek Witkoś (eds.)

2009 Proceedings of the 2nd Student Conference on Formal Linguistics. Poznań: School of English.

Miejski stownik slangu i mowy potocznej. <http://www.miejski.pl.>

Mufwene, Salikoko.

2003 "The shared ancestry of African-American and American White Southern Englishes: Some speculations dictated by history", in: Stephen J. Nagle - Sara L. Sanders (eds.), 64-81.

Mufwene, Salikoko S. - John R. Rickford - Guy Bailey - John Baugh (eds.)

1998 African-American English: Structure, history, and use. London: Routledge.

Nagle, Stephen J. - Sara L. Sanders (eds.)

2003 English in the Southern United States. Cambridge: Cambridge University Press.

Online Etymology Dictionary. $<$ http://www.etymonline.com.>

Oxford English Dictionary. ( $2^{\text {nd }}$ edition.) $<$ www.oed.com. $>$

Pietrzycka-Bohosiewicz, Krystyna - Aleksander Wawrzyńczak - Władysław Mariczenko (eds.)

2005 Stowianie w Europie: Historia, Kultura, Język 2. Kraków: Poligrafix.

Rickford, John Russell - Russell John Rickford

2000 Spoken soul: The story of Black English. New York: John Wiley \& Sons.

Smith, Connie Chic

2012 From the margins to the center: African American English Vernacular in mainstream America, 1995-2010. [Unpublished Ph.D. dissertation, Howard University.]

Smitherman, Geneva

1973 "The power of rap: The Black idiom and the new Black poetry", Twentieth Century Literature 19: 259-274.

1974 "Soul'n Style", The English Journal 63: 16-17.

2000 Black Talk: Words and phrases from the Hood to the Amen Corner. Revised Edition. Boston \& New York: Houghton Mifflin.

Smitherman, Geneva

2006 Word from the mother: Language and African Americans. New York \& London: Routledge. 